\title{
The role of institutional potential and social entrepreneurship as the main drivers of business opportunity and competitiveness
}

\author{
P. Eko Prasetyo ${ }^{a^{*}}$, Andryan Setyadharma ${ }^{\mathrm{b}}$ and Nurjannah Rahayu Kistantic
}

${ }^{a}$ Professor, Department of Development Economics, Faculty of Economics, Universitas Negeri Semarang, Indonesia ${ }^{b}$ Ph.D., Department of Development Economics, Faculty of Economics, Universitas Negeri Semarang, Indonesia ${ }^{c}$ Lecture, Departement of Development Economics, Faculty of Economics, Universitas Negeri Semarang, Indonesia

\section{A B S T R A C T}

\begin{tabular}{l} 
Article history: \\
Received July 16, 2021 \\
Received in revised format \\
September 20, 2021 \\
Accepted October 102021 \\
Available online \\
October 102021 \\
\hline Keywords: \\
Institutional Potential \\
Social Entrepreneurship \\
Business Opportunities \\
Competitiveness
\end{tabular}

\begin{abstract}
Institutional potential plays a key role in creating business opportunities. However, past studies did not emphasize on the consistency and the interaction between institutional and entrepreneurial potential-shaping factors. This research aimed to explore the role of these two aspects in spotting market gaps and encouraging competitiveness. Mixed methods were used, with basic concepts focusing on new institutional economic theory. The results showed that standardization, commercialization, technology, productivity, invention, social capital, and human capital strengthened institutional potential and social entrepreneurship. This created more ventures and encouraged competition. However, there is a need to eliminate institutional barriers to improve the efficiency and productivity of the socio-cultural-economic systems.
\end{abstract}

(C) 2022 Growing Science Ltd. All rights reserved.

\section{Introduction}

According to Mario (2021), determinants of non-standard employment at the industry level include economic performance, institutional and labor factors. ADB (2016), Praseteryo et al. (2020e), Al-Qudah et al. (2021) revealed that potential sustainable economic growth and development are influenced by increased productivity and institutional performance, social entrepreneurship, and business competitiveness. Moreover, ADB (2016) suggested that misallocation is the determinant of total productivity. The new institutional theory advises economic and social systems to reform institutional barriers to improve productivity and efficiency. Guild (2019) established that the poor institutional design of the renewable energy sector creates a regulatory incentive structure that does not align with the political class. As a result, it joined the list of obstacles to institutional potential in Indonesia. Combined with inadequate information and other uncertainties, unreliable designs are the major institutional barriers (Mitjans, 2020; Cavallaro, 2021). The ADB (2016) results based on data from 62 developing countries revealed and suggested policies to eliminate institutional barriers that drive misallocation. Institutional reforms are meant to change regulations that impair productivity and efficiency for economic growth. Zhao (2021) showed that economic reform outweighs political ones for growing the economy. A study by Al-Qudah et al. (2021) with case-studies from 15 countries showed a promising connection between social entrepreneurship and institutions with sustainable development.

Prasetyo et al. (2021) suggested that the new institutional economic theory (NIE), human and social capital, mission, innovation, and networks affected the development of sustainable entrepreneurial ventures. New institutions gained a competitive edge after forming partnerships and integrating innovation, technology, and productivity (Prasetyo, 2021). Social entrepreneurship has received wide acclaim from institutional economies, commercialization, digitalization, sustainable social entrepreneurship, and social novation (Al-Qudah et al., 2021; Prasetyo, 2019). Previously, this model was recognized

* Corresponding author

E-mail address: pekoprasetyo@mail.unnes.ac.id (P. E. Prasetyo)

(C) 2022 Growing Science Ltd. All rights reserved.

doi: $10.5267 /$ j.uscm.2021.10.006 
for the provision of state-sponsored health services in the UK (Roy et al., 2014) due to its ability to link income and health problems. Theoretically and empirically, there is more to be explained on the relationship between social entrepreneurship, health, and well-being (Roy \& Hazenberg, 2019). For this reason, the roles and functions of the larger institutional configuration and its interrelationships in institutional theory and entrepreneurship research can be adjusted (Stephan, 2014). In general, the theory (NIE) of social entrepreneurship will ease the formulation of society-developing initiatives for future practitioners and policy-making institutions. Guerrero and Urbano (2020) stated that institutions could influence how social life is organized and facilitate the functioning of social systems. However, no research has explored social entrepreneurship from this perspective. Others tried integrating social workers and public administration into institutional change. Nevertheless, it recommended future studies be articulated into social entrepreneurship. Social entrepreneurship and innovation are the main drivers for sustainable competitiveness (Prasetyo, 2021b). Recent studies have examined the connection between culture, institutions, and social outcomes (Acemoglu \& Robinson, 2021). However, there is little to hang onto about the correlations between institutional potential and social entrepreneurship in promoting sustainable competitiveness. This calls for urgent research on the two to encourage the creation of more employment opportunities and the competitiveness of sustainable MSME entrepreneurship. Previous studies have shown that the link between social entrepreneurship and institutions (government and universities) in the entrepreneurial ecosystem attracted success, competitiveness, and innovation development (Leal et al., 2020; Prasetyo, 2021). Some researchers used the theory of social capital, resource environment, productivity, and competitiveness to explain the relationship between institutions and international competitiveness. The results showed the need for advanced methodologies and recommended future research to be comparatively carried out in developing countries. Moreover, interactions in various fields were reassessed to improve institutional strengthening, giving entrepreneurship a competitive edge. Social and institutional entrepreneurship is a new socio-economic mission with creative, innovative, and productive ideas that can work with potential resource capabilities to develop economic and social values (Prasetyo, 2021a, 2021b). This study aimed at explaining the importance of the tie-in between institutional potential and social entrepreneurship in encouraging the creation of job ventures and MSME competitiveness in Indonesia. Results are expected to provide a critical empirical and theoretical understanding of the institutional potential and social entrepreneurship in developing countries. Furthermore, these results are anticipated to appeal to scientific reference and policy information to improve job creation, economic growth, and sustainable competitiveness.

\section{Literature Review}

Institutional and resource dependence theories can help explain institutional change. However, these concepts only predicted changes when combined (Sherer \& Lee, 2002). This study integrated the theory of resource dependence and institutional, referred to as the New Institutional Economic theory (NIE). From an economic perspective, NIE has tried expanding the economy by focusing on institutional, social, cultural, and legal rules. Social entrepreneurship in this study is a resource effort to achieve a fair balance. Simón-Moya and Rodríguez-García (2021) established that social entrepreneurship could be an institutional entrepreneur if the need to move from one equilibrium to another arises. Evolutionary theory (NIE) can currently understand the results of increasingly complex interaction systems and processes in sustainable micro, meso, and macro socio-economic structures (Currie et al., 2021; Roy \& Herzenberg, 2019). This theory provided a useful framework for synthesizing institutional regulatory information (Currie et al., 2021). Social entrepreneurship requires an institutional environment for further development (Roy \& Herzenberg, 2019). Institutional rules can facilitate potential solutions for social entrepreneurship performance at the functional level (Currie et al., 2021). In other words, this business model applies to NIE. The two can strengthen institutional potential and social entrepreneurship to create more job opportunities. The theories of economic development by Schumpeter, Keynesianism, and Marxism are applicable for underlying institutional and entrepreneurial correlations in sustainable economic development (Prasetyo, 2020b; Henrekson, 2021; Langroodi, 2021). Furthermore, post-Keynesian and Neo-Schumpeterian theories can be a new institutional theoretical approach to study economic behavior under various and rational uncertainties (Dequech, 2006, 2007; Heise, 2019; Grebel, 2007). The NIE theory and social entrepreneurship are derived from these theories. Basic concepts of the "Schumpeter effect" and "refugee effect" are related to this study. According to the refugee effect theory, unemployment causes the growth of entrepreneurship. This is because unemployed people can innovatively create new jobs. The Schumpeter effect states that every entrepreneurial venture provided new job opportunities, products, and markets (Prasetyo, 2020c). Collaboration and integration of various determinants and institutional causalities with social entrepreneurship are highly encouraged to create more business opportunities. Nevertheless, it improves sustainable entrepreneurial competitiveness (Prasetyo, 2021a). Applying this institutional theory gained momentum, proving to be helpful for entrepreneurship research (Bruton et al., 2010; Kalantaridis \& Fletcher, 2012; Krasniqi \& Desai, 2016; Alaydi, 2021). As an analytical tool, it can be applied by academics and practitioners to criticize the field of social entrepreneurship (Agrawal, 2013). Entrepreneurial theory, social entrepreneurship, in particular, facilitated new institutional changes and transitions in economic development (Elert \& Henreksona, 2020). This approach is also a resource factor that fills deficiencies that institutions cannot perform (Prasetyo, 2020a). Also, it contributes to the construction of the collective dimension associated with social innovation (Fridhi, 2021). Social entrepreneurship initiates innovative activities and sustainable development of financial institutions targeted at social issues (Brajević et al., 2021). Previously, Sivalingam et al. (2020) recommended social entrepreneurs to focus on central issues and more attentionseeking problems to restore the balance of the working world and embrace working with various government institutions.

The new institutional theory formed the basis for discussing the institutional foundations and influences that shape the employment and labor market (De Jong, 2007). However, studies showed that institutional strength justified the market 
structure for disadvantaged temporary job positions (De Jong, 2007). The new institutional theory revolution viewed the market in a wider and complex scope (Currie, 2021; Roy et al., 2019). Moreover, recent research confirmed that the NIE theory simplifies the complexities of local government for easy understanding. Roy et al. (2018) revealed that economic efficiency partially explained economic performance but is not considered a determining factor. Literature studies based on the theory of human capital resources described how social enterprise programs (SEP) in social entrepreneurship encouraged sustainable economic growth and development (Prasetyo et al., 2020b; Weaver, 2016).

Recent empirical studies examined the field conditions that social entrepreneurship can be institutionalized and change existing institutions (Chatzichristos \& Nagopoulos, 2021). The results revealed that the institutionalization of social entrepreneurship could be developed and decentralized. This allows social entrepreneurship to remain autonomous and encourages the spread of new institutional logic in the future (Chatzichristos \& Nagopoulos, 2021). For Chatzicgristos and Nagopoulos (2011), customizing such embodied voluntary collective action had significant limitations. Another empirical study investigated the impact of social enterprises on skills and employment development in the UK (Roy \& Hazenberg, 2019). The results showed a significant impact had been generated in the sector, but the policy implications remained nonconducive for social entrepreneurship. This approach encouraged the improvement of population skills by creating new jobs (Roy \& Hazenberg, 2021).

Peters (2020) had the same option that in the new growth theory, more job opportunities arose from the ever-changing technology applied economic activities in the new growth theory. Institutional theory, however, formed the basis for understanding the ways entrepreneurs create new products or services and seek legitimacy to create their new business opportunities and products (Bruton et al., 2010; Prasetyo, 2020d). Furthermore, Prasetyo (2020d) suggested that carrying out new product development (NPD) on value chain strategies is a great way of achieving sustainable entrepreneurial competitiveness.

Other recent empirical studies also analyzed the influence of institutional, economic, and socio-economic determinants of culture on total entrepreneurial activity in developed and developing countries (Prasetyo, 2021). The results showed that the more efficient state institutions are, the higher the level of entrepreneurial activity and new job opportunities. In general, unexplored market gaps are a better part of the value chain that connects institutions to the wider socio-economic and entrepreneurial culture, inequality, patterns of innovation, economic growth, and employment (Prasetyo, 2021; Wood \& Allen, 2019). This study was also based on a framework with a novelty that focused on highlighting the importance of linking new institutional potential and social entrepreneurship. The results are expected to be used in regional and national institutional systems to provide significant additional explanations about entrepreneurial performance in various countries (Carney et al., 2018).

\section{Research Method}

This study used mixed methods to solve the main problem and meet the objectives. The design was compiled based on a research framework to explain the important role of institutional potential and social entrepreneurship. The objective of this research was to establish a simple model that encourages the creation of new job opportunities and entrepreneurial competitiveness. The mixed methods were also designed with an exploratory technique as the initial step that underlies the formation of this simple model. The basic analysis model used multiple regression path analysis. All variables were measured then an experimental regression model method was carried out to find the best simple model in path analysis.

Operational definitions and variable measurement dimensions used the Gini ratio index value. The studies began with qualitative methods and exploratory analysis complemented by quantitative techniques. The explorative, descriptive quantitative analysis method explained every phenomenon found, measured, formulated, and modeled. Some variables used in the model formation include Business Opportunity (BO), Social Entrepreneurship (SE), Institutional (In), Standardization (St), Commercialization (Cz), and Technology (Tg). Others were Productivity (Pd), Invention (Iv), Social Capital (SC), Human Capital (HC), and Competitiveness (Cp). To better understand the phenomena, research problems, and how objectives were achieved, relevant research designs and step-by-step diagrams were drawn up from the above framework. Structural equations of the regression model and path analysis were also rearranged to make the research easily understood.

$$
\begin{aligned}
& B O_{i}=\alpha_{0}+\beta_{1} S E_{i}+\beta_{2} I n_{i}+\beta_{3} S t_{i}+\varepsilon_{1} \\
& B O_{i}=\alpha_{0}+\beta_{1} S E_{i}+\beta_{2} I n_{i}+\beta_{4} C z_{i}+\varepsilon_{2} \\
& B O_{i}=\alpha_{0}+\beta_{1} S E_{i}+\beta_{2} I n_{i}+\beta_{5} T g_{i}+\varepsilon_{3} \\
& B O_{i}=\alpha_{0}+\beta_{1} S E_{i}+\beta_{2} I n_{i}+\beta_{6} P d_{i}+\varepsilon_{4} \\
& B O_{i}=\alpha_{0}+\beta_{1} S E_{i}+\beta_{2} I n_{i}+\beta_{7} I v_{i}+\varepsilon_{5} \\
& B O_{i}=\alpha_{0}+\beta_{1} S E_{i}+\beta_{2} I n_{i}+\beta_{8} S C_{i}+\beta_{9} H C_{i}+\varepsilon_{6} \\
& C m_{i}=\alpha_{0}+\beta_{1} S E_{i}+\beta_{2} I n_{i}+\beta_{9} H C_{i}+\beta_{10} B O_{i}+\varepsilon_{7}
\end{aligned}
$$




\section{Results and Discussion}

The study focused more on the least investigated institutional potential and social entrepreneurship. Previous research showed important institutions for entrepreneurship (Bruton et al., 2010; Krueger, 2020; Aparicio et al., 2021). However, Bruton's research (2010) centered on informal institutions, social norms, and cognitive scripts because they regulate human behavior. Aparicio (2021) was drawn to social entrepreneurship. With that in mind, the research explained the combination of institutional and social entrepreneurship variables based on the theoretical concept of "Schumpeter effect" and "refugee effect." Schumpeter's entrepreneurship creates new companies and institutional systems that can support social entrepreneurship. Based on this theory, any newly established social entrepreneurship provides more business opportunities and markets (Prasetyo, 2020b). The "refugee effect" theory, however, stated that creative unemployed people could create social entrepreneurship and business opportunities. This concurred with Schumpeter's entrepreneurship that supports the development of more companies and changes new institutions in the entrepreneurial creativity support system (Henrekson et al., 2021).

The Indonesian government is tirelessly working to develop its industrial sector based on Schumpeter's entrepreneurial culture that is more creative, innovative, and productive. That said, research aimed to explain the role of institutional potential and social entrepreneurship with variables including standardization, commercialization, technology, productivity, invention, human and social capital in creating new business opportunities and competitiveness. Table- 1 shows the result of the models that were compiled and written in the research sub-method above. These five models show that institutional potential and social entrepreneurship variables are consistently positive and significantly able to create new business opportunities in Indonesia. In conclusion, the study revealed new details about the action of institutional potential and social entrepreneurship on job opportunities and competitiveness.

Previous research confirmed that standardization and commercialization could strategically increase regional and national economic competitiveness and growth (Prasetyo, 2019a). These previous findings are strengthened with results in models 1 and 2 in Table 1. Standardization improved the quality of products for excellent commercialization and competitiveness (Prasetyo, 2019a). Moreover, it triggered inventions and provided quality assurance to consumers. Local governments or related institutions should have defined roles in standardization, commercialization, and innovation to encourage regional competitiveness and economic growth (Prasetyo, 2019a). The results in Table 1 also strengthen the role of institutional potential and social entrepreneurship in encouraging the creation of new business opportunities and entrepreneurial competitiveness.

Table 1

Multiple linear regression model of increasing entrepreneurial business opportunities

\begin{tabular}{|c|c|c|c|c|c|c|c|c|}
\hline \multirow{2}{*}{\multicolumn{2}{|c|}{ Model }} & \multicolumn{2}{|c|}{$\begin{array}{l}\text { Unstandardized } \\
\text { Coefficients }\end{array}$} & \multirow{2}{*}{$\begin{array}{c}\begin{array}{c}\text { Standardized } \\
\text { Coefficients }\end{array} \\
\text { Beta }\end{array}$} & \multirow[t]{2}{*}{ t-stc } & \multirow[t]{2}{*}{ Sig. } & \multicolumn{2}{|c|}{ Collinearity Statistics } \\
\hline & & $\mathrm{B}$ & Std. Error & & & & Tolerance & VIF \\
\hline \multirow[t]{4}{*}{1} & (Constant) & -.114 & .029 & & -3.914 & .000 & & \\
\hline & Social_Entrepreneurship & .416 & .057 & .382 & 7.273 & .000 & .535 & 1.868 \\
\hline & Institutional & .503 & .081 & .388 & 6.172 & .000 & .373 & 2.677 \\
\hline & Standardization & .245 & .050 & .267 & 4.925 & .000 & .502 & 1.991 \\
\hline \multirow[t]{4}{*}{2} & (Constant) & -.098 & .032 & & -3.013 & .003 & & \\
\hline & Social_Entrepreneurship & .432 & .059 & .396 & 7.262 & .000 & .539 & 1.857 \\
\hline & Institutional & .499 & .095 & .386 & 5.255 & .000 & .298 & 3.354 \\
\hline & Commercialization & .202 & .057 & .230 & 3.551 & .001 & .384 & 2.607 \\
\hline \multirow[t]{4}{*}{3} & (Constant) & -.108 & .032 & & -3.370 & .001 & & \\
\hline & Social_Entrepreneurship & .389 & .062 & .357 & 6.280 & .000 & .503 & 1.986 \\
\hline & Institutional & .553 & .088 & .427 & 6.249 & .000 & .349 & 2.867 \\
\hline & Technology & .203 & .062 & .215 & 3.272 & .001 & .378 & 2.644 \\
\hline \multirow[t]{4}{*}{4} & (Constant) & -.099 & .039 & & -2.512 & .013 & & \\
\hline & Social_Entrepreneurship & .389 & .068 & .358 & 5.763 & .000 & .447 & 2.236 \\
\hline & Institutional & .587 & .104 & .454 & 5.623 & .000 & .265 & 3.775 \\
\hline & Productivity & .144 & .078 & .162 & 1.847 & .067 & .224 & 4.468 \\
\hline \multirow[t]{4}{*}{5} & (Constant) & -.114 & .033 & & -3.426 & .001 & & \\
\hline & Social_Entrepreneurship & .457 & .061 & .419 & 7.441 & .000 & .533 & 1.875 \\
\hline & Institutional & .548 & .104 & .424 & 5.252 & .000 & .261 & 3.836 \\
\hline & Invention & .148 & .063 & .160 & 2.352 & .020 & .367 & 2.724 \\
\hline
\end{tabular}

Source: processed by researchers

Analyzing the quantity and quality of potential entrepreneurs informed how to maintain a healthy entrepreneurial activity (Krueger, 2020). This makes institutional potential and social entrepreneurship either directly or indirectly important determinants in encouraging the creation of new business opportunities and entrepreneurial competitiveness. Furthermore, the role of these two variables is useful in proving the basic concept of the Schumpeter effect theory. The above results also strengthen previous findings that social entrepreneurship and institutional potential affected each other (Prasetyo, 2020b). The institutional dimension in this research was generated from informal institutions. However, the findings do not distinguish between formal and informal institutions, which differs slightly from Aparicio's (2021). This study stated that social entrepreneurship and policies can influence formal institutions directly. Entrepreneurship has an indirect effect and can change formal institutions through business activities to avoid outdated regulations. In this research, the outdated 
regulations, especially the corrupt, inefficient, and ineffective bureaucracy, are the main institutionalization obstacles. This shows a great need for quality institutional leadership in Indonesia for better social entrepreneurship in society. According to this result, leadership should accept the institutional complexity phenomenon inherent in social entrepreneurship activities instead of ambitious institutional stakeholders that may fail the organization. Kickkul (2020) insisted that addressing these institutional complexities should be included in social entrepreneurship training.

Dimension of this study investigated institutional potential in an informal form, making inhibiting factors less perceptible. The role of informal institutions is a more interesting finding that may change people's behavior, drawing them to the growth of the social entrepreneurship potential. These interests and aspirations can only be nurtured from a social entrepreneurship background with an entrepreneurial spirit, human capital resource capacity, and better technology absorption. Furthermore, aspects of entrepreneurial social culture and institutional potential are needed to maintain the sustainability of entrepreneurship. These results sail together with research that revealed cultural and institutional aspects that made it easy to understand human behavior, individual choices, and patterns of society (Andriani \&Bruno, 2021). Human behavior is driven by socio-cultural norms, including the principle of social interaction "tuna satak bathi sanak" might be a survival strategy, despite institutional constraints and economic sanctions in various socio-economic contexts (Prasetyo, 2020e; Andriani \& Bruno, 2021; Andersson et al., 2021). Meanwhile, Andersson et al. (2021) stated that economic development in Indonesia includes a process through socio-cultural capabilities and is not limited to the role of state institutions. This means that the pattern of human cultural behavior that is uncorrupt and applicable norms has helped eliminate institutional barriers. Institutions with no potential practice corruption, reducing the entrepreneurial community's enthusiasm, joy, and happiness. This lowers the institutional potential and social entrepreneurship, limiting business opportunities and entrepreneurial competitiveness. Cultural and other factors were modeled in this research, and the results show in tables 1 and 2 . The models indicate that various resource variables, including standardization, commercialization further strengthen social entrepreneurship potential in promoting new business opportunities and competitiveness. Based on Tables 1 and 2 , models 1 to 5 are scientifically promising and contribute to the increasing business ventures and tough competition.

Table 2

Determination of the model of factors influencing entrepreneurial business opportunities

\begin{tabular}{|c|c|c|c|c|c|c|c|c|c|c|}
\hline \multirow[b]{2}{*}{ Model } & \multirow[b]{2}{*}{$\frac{\mathrm{R}}{\text { Multiple }}$} & \multirow[b]{2}{*}{ R Square } & \multirow[b]{2}{*}{$\begin{array}{l}\text { Adjusted R } \\
\text { Square }\end{array}$} & \multirow[b]{2}{*}{$\begin{array}{l}\text { Std. Error of the } \\
\text { Estimate }\end{array}$} & \multicolumn{5}{|c|}{ Change Statistics } & \multirow[b]{2}{*}{$\begin{array}{l}\text { Durbin- } \\
\text { Watson }\end{array}$} \\
\hline & & & & & $\begin{array}{l}\text { R Square } \\
\text { Change }\end{array}$ & F Change & df1 & df2 & $\begin{array}{l}\text { Sig. F } \\
\text { Change }\end{array}$ & \\
\hline 1 & .906 & .821 & .817 & .112672 & .821 & 185.424 & 3 & 121 & .000 & 1.734 \\
\hline 2 & .898 & .806 & .801 & .117479 & .806 & 167.326 & 3 & 121 & .000 & 1.792 \\
\hline 3 & .896 & .803 & .798 & .118326 & .803 & 164.365 & 3 & 121 & .000 & 1.722 \\
\hline 4 & .890 & .791 & .786 & .121745 & .791 & 153.028 & 3 & 121 & .000 & 1.777 \\
\hline 5 & .892 & .795 & .790 & .120721 & .795 & 156.322 & 3 & 121 & .000 & 1.722 \\
\hline
\end{tabular}

Institutional potential and social entrepreneurship worked for job opportunities and competitiveness. Empirical studies, however, revealed that social entrepreneurship partially influenced competition and sustainable national economic growth. Based on the experimental test research, social entrepreneurship significantly affected the creation of new job opportunities and sustainable entrepreneurial competitiveness. However, social entrepreneurship was unable to promote sustainable national economic growth. Results on the role of institutional potential showed that it could become the main tool in creating new business opportunities and sustainable entrepreneurial competitiveness. Although the role of institutional potential and social entrepreneurship is important, the capacity of human capital resources is the main determinant of entrepreneurial performance (Prasetyo, 2020b).

Table 3

The path analysis model results of increasing entrepreneurial business opportunities

\begin{tabular}{|c|c|c|c|c|c|c|}
\hline \multicolumn{2}{|r|}{ Model } & \multicolumn{2}{|c|}{ Unstandardized Coefficients } & \multirow{2}{*}{$\frac{\text { Standardized }}{\text { Beta }}$} & \multirow[t]{2}{*}{ t-stc. } & \multirow[t]{2}{*}{ Sig. } \\
\hline & & $\mathrm{B}$ & Std. Error & & & \\
\hline \multirow[t]{5}{*}{6} & (Constant) & -.129 & .030 & & -4.357 & .000 \\
\hline & Social_Entrepreneurship & .301 & .079 & .277 & 3.800 & .000 \\
\hline & Institutional & .479 & .096 & .370 & 4.978 & .000 \\
\hline & Social_Capital & .255 & .089 & .222 & 2.870 & .005 \\
\hline & Human_capital & .167 & .062 & .159 & 2.710 & .008 \\
\hline \multirow{5}{*}{7} & (Constant) & -.131 & .030 & & -4.412 & .000 \\
\hline & Social_Entrepreneurship & .143 & .059 & .138 & 2.408 & .018 \\
\hline & Institutional & .445 & .106 & .361 & 4.200 & .000 \\
\hline & Human_Capital & .219 & .062 & .219 & 3.530 & .001 \\
\hline & Business_Opportunity & .283 & .054 & .316 & 5.263 & .000 \\
\hline
\end{tabular}

Source: processed by researchers

Based on the results in Table 3, model-6 shows that institutional potential and social entrepreneurship dominate the role of main resources (human and social capital). In model-7, the role of institutional factors positively and significantly provides the first largest contribution. However, the role of social entrepreneurship resources has decreased slightly. This empirical research found that the existence of institutional barriers impacted decreasing the social value of the community. Also, the potential for institutional strengthening social equity through the social value created. This means that the role of institutional 
change can be the main driver of entrepreneurial competitiveness and an obstacle to social entrepreneurship, showing how institutional complexity is becoming dynamic. These results support previous studies that stated that institutional complexity is not a constraint but can be a resource in a dynamic process for sustainable social value creation in developing countries (Cherrier et al., 2018).

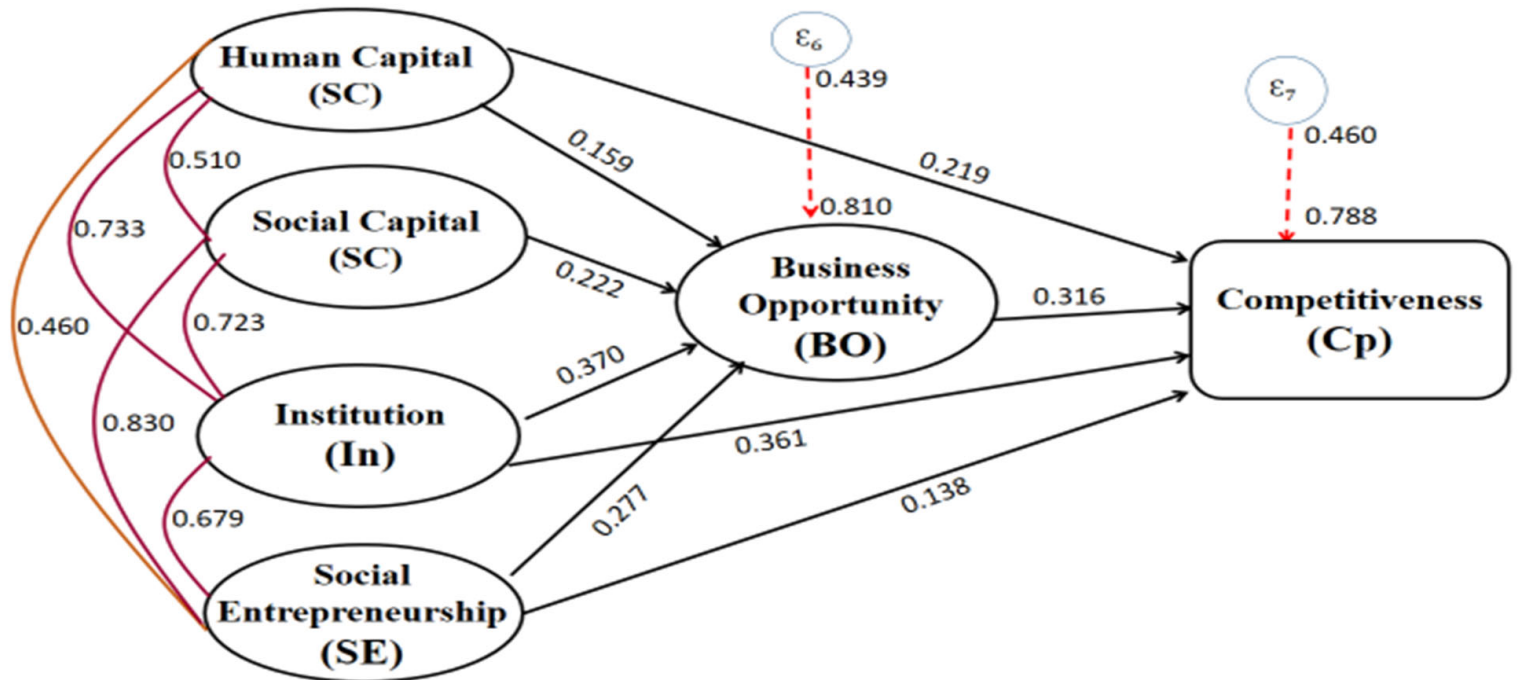

Fig.1. Path analysis model of increasing job opportunities and entrepreneurial competitiveness Source: processed by researchers

Fig. 1 shows that the role of institutional potential and its total effect are directly or indirectly the main drivers of business opportunities and sustainable competitiveness. Social entrepreneurship provides the second-largest contribution directly to creating new job opportunities and indirectly to the increase of sustainable entrepreneurial competitiveness. This phenomenon has policy implications that focus on reforming all economic and political-institutional barriers to increase institutional potential. As a result, the new institutional socio-economic, cultural system becomes more productive and efficient in creating social and economic equity for the community.

This research confirmed that informal institutional potential shapes the social capital structure. When the social capital structure collaborates with human capital, they form stronger social entrepreneurship. Integrating human capital with dynamic institutional potential changes may attract success in social entrepreneurship. Furthermore, the interaction between institutional potential and social entrepreneurship improves sustainable economic growth and competitiveness. Dynamic new institutional changes can speed up the integration of the resource dependence and institutional change theory to strengthen the basic concepts of the new institutional economic (NIE) theory.

\section{Conclusion}

Investing in quality human capital and technology absorption is essential for institutional potential and social entrepreneurship. With quality human capital capacity, mastering technology can be easy. This increases job opportunities, productivity, competitiveness, and quality of institutional potential and social entrepreneurship. Commitment and facilitation of quality institutional potential are needed for improved sustainability of human capital quality. This is because complexity from positive changes in institutional potential cannot maintain human capital capacity and productivity. However, it can significantly and consistently contribute to creating business opportunities and sustainable competitiveness directly or indirectly. The complexity of the institution can negatively affect the exploitation of resources, reducing productivity. This may delay the socio-economic equity of the community.

The NIE theory relies on the capacity of human resources and technology as the main foundation for the ever-changing institutional potential complexity. However, the institutional potential further strengthens the resource dependence theory's capacity to create business opportunities, labor markets, and entrepreneurial competitiveness. The correlation between institutional potential and social entrepreneurship resources provides business opportunities and improves competitiveness. Moreover, it regulates efforts, speeding up the achievement of socio-economic equity. Policy implications should regulate and reform institutional barriers to improve the functionality of the socio-cultural-economic system.

\section{Acknowledgements}

The researcher would like to thank the Directorate General of Higher Education DRPM, Directorate of the Ministry of Education, Culture and Research and Technology of the Republic of Indonesia. Because the research on the PDUPT Decentralization scheme is supported by funding based on the main contract and its derivatives: DRPM: 044/SP2H/LT/DRPM/2021 and SPPK Capacity: 044/E4.1/AK.04.PT/2021. 


\section{Conflicts of Interest}

1) The author is responsible and states; there is no potential conflict of interest of any kind in connection with this research, either before and after its implementation, and/or publication of this article.

2) The author guarantees that this article is the original work of the author himself that has not been published, and at this time it is only sent for publication in the journal Entrepreneurship: Theory and Practice. As part of this process, this article is not being submitted and is being considered for publication elsewhere.

\section{References}

Acemoglu, D., \& Robinson, J. A. (2021). Culture, Institutions and Social Equilibria: A Framework (No. w28832). National Bureau of Economic Research.

Agrawal, A., \& Hockerts, K. (2013). Institutional theory as a framework for practitioners of social entrepreneurship. Social Innovation: Solutions for a Sustainable Future, Springer Berlin Heidelberg, 119-129.

Alaydi, S. R. (2021) Entrepreneurship and institutional challenges: disincentives or opportunities? Case studies in the Palestinian mobile phone sector. PhD thesis. Adam Smith Business School: University of Glasgow. http://theses.gla.ac.uk/82053/

Andersson, M., Axelsson, T., \& Palacio, A. (2021). Resilience to economic shrinking in an emerging economy: the role of social capabilities in Indonesia, 1950-2015. Journal of Institutional Economics, 17(5), 509-526

Andriani, L., \& Bruno, R.L. (2021). Introduction to the special issue on institutions and culture in economic contexts. Journal of Institutional Economics, 17(5), 1-14.

Aparicio, B., Urbano, D., \& Stenholm, P. (2021). Attracting the entrepreneurial potential: A multilevel institutional approach. Technological Forecasting \& Social Change, 168(2021), 120748

Al-Qudah, A.A., Al-Okaily, M., \& Alqudah, H. (2021). The relationship between social entrepreneurship and sustainable development from economic growth perspective: 15 'RCEP' countries. Journal of Sustainable Finance \& Investment, 9(2),1-18. doi.10.1080/20430795.2021.1880219

Brajević, S., Babić, A., \& Jukić, I. (2021), Social Entrepreneurship and Economic Development. Journal International Economic Meeting, 2(1), 156-166

Bruton, G.D., Ahlstromm, D., \& Li, H.L. (2010). Institutional Theory and Entrepreneurship: Where Are We Now and Where Do We Need to Move in the Future. Entrepreneurship Theory and Practice, 34(3), 421-440.

Carney, M., Estrin, S., Shapiro, D., \& Liang, Z. (2018). National institutional systems, foreign ownership and firm performance: the case of understudied countries. Journal of World Business, 54(4), 244-257.

Cavallaro, M., \& Lepori, B. (2021). Institutional barriers to participation in EU framework programs: contrasting the Swiss and UK cases. Scientometrics, 126,1311-1328.

Cherrier, H., Goswami, P., \& Ray, S. (2018). Social entrepreneurship: Creating value in the context of institutional complexity. Journal of Business Research, 86(5), 245-258.

Chatzichristos, G., \& Nagopoulos, N. (2021). Social entrepreneurs as institutional entrepreneurs: evidence from a comparative case study. Social Enterprise Journal.

Currie, T.E., Campenni, M., Flitton, A., Njagi, T., Ontiri, O., Perret C., \& Walker, L. (2021). The cultural evolution and ecology of institutions. Philosophical Transactions of the Royal Society B, 376(1828), 1-14.

De Jong, J.P., Schalk, R., \& Goessling, T. (2007). An Institutional Perspective on the Employment Position of Temporary Workers in the Netherlands. Jounal Relations Industrial Relations, 62(3), 492-515.

Dequech, D. (2006). The new institutional economics and the theory of behaviour under uncertainty. Journal of Economic Behavior \& Organization, 59(2), 109-131.

Dilli, S., Elert, N., \& Herrmann, A.M. (2018). Varieties of entrepreneurship: exploring the institutional foundations of different entrepreneurship types through 'Varieties-of-Capitalism' arguments. Small Business Economy, 51(2), 293-320.

Elert, N., \& Henreksona, M. (2020). Entrepreneurship Prompts Institutional Change in Developing Economies. Research Institute of Industrial Economics, 1313, 1-25.

Fridhi, B. (2021). Social entrepreneurship and social enterprise phenomenon: toward a collective approach to social innovation in Tunisia. Journal of Innovation and Entrepreneurship, 10(14), 1-21. https://doi.org/10.1186/s13731-02100148-6

Grebel, T. (2007). Neo-Schumpeterian perspectives in entrepreneurship research. Edward Elgar Publishing Limited, Chapter, 9, 147-158.

Guerrero, M., \& Urbano, D. (2020) Institutional conditions and social innovations in emerging economies: insights from Mexican enterprises' initiatives for protecting/preventing the effect of violent events. The Journal of Technology Transfer, 45(4), 929-957.

Guild, E., Basaran, T., \& Allinson, K. (2019). From Zero to Hero? An analysis of the human rights protections within the Global Compact for Safe, Orderly and Regular Migration (GCM). International Migration, 57(6), 43-59.

Heise, A. (2019). Post-Keynesian Economics - Challenging the Neo-Classical Mainstream. Journal of Economic Research, 2(8), 8-29. 
Henrekson, M., Karna, A., \& Sanandaji, T. (2021). Schumpeterian Entrepreneurship: Coveted by Policymakers but Impervious to Top-Down Policymaking. Research Institute of Industrial Economics, 1395, 1-27.

Kalantaridis, C., \& Fletcher, D. (2012). Entrepreneurship and Institutional Change: A Research Agenda. Entrepreneurship and Regional Development, 24(3-4), 199-214.

Krueger, P., Sautner, Z., \& Starks, L. T. (2020). The importance of climate risks for institutional investors. The Review of Financial Studies, 33(3), 1067-1111.

Kickul, J., \& Lyons, T.S. (2020). Understanding Social Entrepreneurship: The Relentless Pursuit of Mission in an Ever Changing World, 3rd Ed. New York, NY: Routledge

Krasniqi, B., \& Desai, S. (2016). Institutional Drivers of High-Growth Firms: Country-Level Evidence from 26 Transition Economies. Small Business Economics, 47(4), 1075-1094.

Leal, N.F., Ordaz, C.C., Gonzalez, J.P.D., \& Ginel, E.S. (2020). The Role of Social and Institutional Contexts in Social Innovations of Spanish Academic Spinoffs. Sustainability, 2020(12), 906; doi:10.3390/su12030906.

Mario, P., \& Reljic, J. (2021). Employment quality, economic performance and wages in Europe. Exploring the virtuous circle. MPRA Working Paper; September 2021, https://mpra.ub.uni-muenchen.de/109797/

Messner, S. F., Rosenfeld, R., \& Karstedt, S. (2013). Social institutions and crime. In F. T. Cullen \& P. Wilcox (Eds.), The Oxford Handbook of Criminological Theory (405-423). Oxford: Oxford University Press

Mitjans, F., \& Oxilia, V. (2020). Model of Institutional Analysis of Barriers to Obtain CERs; under the focus of the New Institutional Economy (NIE), using a decision tool multi-criteria: Development and Application to a case in Paraguay. Journal of Environmental Science, Toxicology and Food Technology, 14(5), 43-55.

Langroodi, F.E. (2021). Schumpeter's Theory of Economic Development: A Study of the Creative Destruction and Entrepreneurship Effects on the Economic Growth. Journal of Insurance and Financial Management, 4(3), 65-81.

Peters, M.A. (2020). Beyond Technological Unemployment: The Future of Work. Education Philosophy Theory, 52(2), 485491.

Prasetyo, P. E., Setyadharma, A., \& Kistanti, N. R. (2021). Integration and collaboration of determinants of entrepreneurial competitiveness. Uncertain Supply Chain Management, 9(3), 585-594. doi: 10.5267/j.uscm.2021.6.002.

Prasetyo, P.E., \& Kistanti, N.R. (2020a). Role of Social Entrepreneurship in Supporting Business Opportunities and Entrepreneurship Competitiveness. Open Journal of Business and Management, 8(4), 1412-1425.

Prasetyo, P.E., \& Kistanti, N.R. (2020b) Human Capital, Institutional Economics and Entrepreneurship as a Driver for Quality \& Sustainable Economic Growth. Entrepreneurship and Sustainability Issues, 7(4), 2575-2589.

Prasetyo, P.E., \& Dzaki, F.Z. (2020c). Institutional performance and new product development value chain for entrepreneurial competitive advantage. Uncertain Supply Chain Management, 8(4), 753-760. https://doi.org/10.5267/j.uscm.2020.7.004.

Prasetyo, P.E., Setyadharma, A., \& Kistanti, N.R. (2020d). The Role of Social Capital in New Products Development and Business Competitiveness Enhancement, International Journal of Scientific \& Technology Research, 9(3), $1838-1843$.

Prasetyo, P.E., Setyadharma, A., \& Kistanti, N.R. (2020e). Social Capital: The Main Determinant of MSME Entrepreneurship Competitiveness. International Journal of Scientific \& Technology Research, 9(3), 6627-6637.

Prasetyo, P.E. (2019a). Standardization, Comercialization and Productivity on Doormat Creativity Industries Competitivieness. Journal of Economics and Policy, 12(1), 12-26.

Roy, M.J., Donaldson, C., Baker, R., \& Kerr, S. (2014). The potential of social enterprise to enhance health and well-being: A model and systematic review. Social Science \& Medicine 123(2),182-193.

Roy, M.J., Hazenberg, R., (2019). An Evolutionary Perspective on Social Entrepreneurship 'Ecosystems. A Research Agenda for Social Entrepreneurship, Edward Elgar, 13-22.

Simón-Moya, V., \& Rodríguez-García, M. (2021). Sources of Financing for Social Entrepreneurship. In The Emergence of Social Entrepreneurship (pp. 29-39). Springer, Cham.

Sivalingam, A.D., Zandi, G., \& Mansori, S. (2020). A Conceptual Study on Establishing Social Enterprise Company with Institutional Theory Approach. Social Entrepreneurship eJournal, 10(4), 1-7. http://dx.doi.org/10.2139/ssrn.3722364

Sherer, P. D., \& Lee, K. (2002). Institutional change in large law firms: A resource dependency and institutional perspective. Academy of Management Journal, 45(1), 102-119.

Weaver, R.L. (2016). Social enterprise self-employment programs A two-dimensional human capital investment strategy, Social Entreprise Journal, 12(1), 4-20.

Wood, G.T., \& Allen, M.C. (2019). Institutional theory, business system and employment relations, Edward Elgar Publisher, 169-182.

Zhao, H. L., Wang, L., Liu, F., Liu, H. Q., Zhang, N., \& Zhu, Y. W. (2021). Energy, environment and economy assessment of medical waste disposal technologies in China. Science of The Total Environment, 796, 148964.

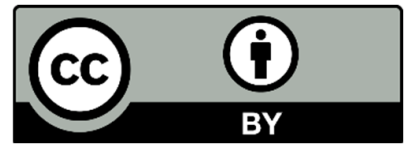

(C) 2022 by the authors; licensee Growing Science, Canada. This is an open access article distributed under the terms and conditions of the Creative Commons Attribution (CCBY) license (http://creativecommons.org/licenses/by/4.0/). 